\title{
Reconstructing Eastern Mediterranean climate during MIS6 and MIS5e from Peqi'in Cave speleothem fluid inclusion stable isotope and $\mathrm{TEX}_{86}$ measurements
}

\author{
ELAN LEVY ${ }^{1}$, MIRYAM BAR-MATTHEWS ${ }^{2}$, HUBERT \\ VONHOF $^{1}$, ALAN ALAN MATTHEWS ${ }^{3}$, AVNER \\ AYALON $^{2}$, ALFREDO MARTINEZ-GARCIA ${ }^{1}$ AND \\ GERALD H. HAUG ${ }^{1,4}$
}

${ }^{1}$ Max Planck Institute for Chemistry

${ }^{2}$ Geological Survey of Israel

${ }^{3}$ Hebrew University of Jerusalem

${ }^{4}$ ETH Zurich

Presenting Author: elanlevy27@gmail.com

Important terrestrial paleo-climate information can be obtained by combining cave speleothem calcium carbonate and measured fluid inclusion (FI) stable isotope data. The FI $\delta^{18} \mathrm{O}\left(\mathrm{H}_{2} \mathrm{O}\right)$ and $\delta^{2} \mathrm{H}\left(\mathrm{H}_{2} \mathrm{O}\right)$ and enable calculation of the $d$-excess values $\left(\delta^{2} \mathrm{H}\left(\mathrm{H}_{2} \mathrm{O}\right)-8 \times \delta^{18} \mathrm{O}\left(\mathrm{H}_{2} \mathrm{O}\right)\right)$. Furthermore, formation temperatures derived from $\mathrm{FI} \delta^{18} \mathrm{O}\left(\mathrm{H}_{2} \mathrm{O}\right)$ and speleothem $\delta^{18} \mathrm{O}\left(\mathrm{CaCO}_{3}\right)$ can now be independently compared with $\mathrm{TEX}_{86}$ derived paleotemperature measurements determined from the analyses of organic GDGTs within speleothems [1]. Here we apply these methodologies to investigate the paleo-climate of the Eastern Mediterranean region during the glacial to interglacial transition from MIS6 to MIS5e (160ka to 120ka), using a speleothem from Peqi' in Cave (northern Israel). Significant variability is found in FI derived temperatures; nevertheless, both the $\mathrm{TEX}_{86}$ and FI derived temperatures (calibrated using the empirical relationship for caves [2]) overlap within error and show a similar general trend of increasing temperature from mid MIS6 $\left(13^{\circ} \mathrm{C}\right.$ for $\mathrm{TEX}_{86}$; and $11^{\circ} \mathrm{C}$ for mean $\left.\mathrm{FI}\right)$ to MIS5e $\left(19^{\circ} \mathrm{C}\right.$ for $\mathrm{TEX}_{86}$; and $15^{\circ} \mathrm{C}$ for mean FI). The FI $\delta^{18} \mathrm{O}\left(\mathrm{H}_{2} \mathrm{O}\right)$ variability with time generally matches by that of $\delta^{18} \mathrm{O}\left(\mathrm{CaCO}_{3}\right)$, shifting from $-5.5 \%$ (vs. VSMOW) during mid MIS6 to $\sim-8.5 \%$ during MIS5e, a period that overlaps with the formation of Mediterranean sapropel 5 (S5). The $\delta^{2} \mathrm{H}\left(\mathrm{H}_{2} \mathrm{O}\right)$ shows a decrease from $\sim-25.1 \%$ during MIS6 to $\sim-46.0 \%$ during MIS5e, with a minimum peak of -50.8 at $\sim 123 \mathrm{ka}$. From late MIS6 to MIS5e the $d$-excess changes from values of 15 to $25 \%$ to higher values of 17 to $35 \%$. Thus, although $d$-excess values are consistently above the GMWL ( $\sim 10 \%)$ and are typical for the Eastern Mediterranean Sea region, they also show an increasing trend, which could have been a result of increased sea surface temperatures and/or atmospheric relative humidity change. The robust FI stable isotope data demonstrate their potential to produce an important climatic record of the glacial to interglacial changes in the northern Eastern Mediterranean region.

[1] Baker, Blyth, Jex, Mcdonald, Woltering \& Khan (2019), Organic Geochemistry 136, p.103890.

[2] Tremaine, Froelich \& Wang (2011), Geochimica et Cosmochimica Acta 75(17), 4929-4950. 